Mr. STrong's suggestion is very ingenious, and I must admit that, granting his prenises, the chance production of an unlimited quantity of a single asymmetric compound is conceivable. I had not thought of the possibility of one asymmetric molecule acting as a catalytic agent in the way he suggests. It would, however, have been perhaps simpler and more in accord ance with the behaviour of enzymes, with which class of ferments he compares this supposed catalytic agent, if he had represented the second stage of the process as a hydrolysis; in which case, of course, the asymmetric group of the resulting compound would have contained hydroxyl in place of hydrogen.

Mr. Strong admits that the process is "purely hypothetical." I think I should go further than this, and say that, considered as an actual process occurring under chance conditions, it is grotesquely improbable.

The "volcanic explosion" carrying "one molecule" of an asymmetric compound into "a certain pool of water," seems to be a reproduction (on a reduced scale) of Prof. Errera's "vortex" which whirks "one simply asymmetric particle" into a particular "planet" (see NATURE, vol. lviii. p. 6r6, col. 2).

The University, Aberdeen, November 5. F. R. JAPI'

\section{Mental Calculations of a High Order.}

THERE are probably among your readers some who are interested, by curiosity or for scientific purposes, in freaks of memory. I am not sure that what my memory has done is remarkable, at though it is quite novel to me.

For many years $I$ have been in the habit of using some useless exercise in mental gymnastics to divert my mind from the occupations of the day, and so get quickly asleep. Sometimes it would be extracting the letters of the alphabet successively from some passage in prose or poetry, keeping the number of each letter in mind, and finally counting all the letters in the passage, to make sure that I had allowed no letter to pass by me unnoticed. Again, I would try to think of all the famous poets, or generals, or sovereigns, or statesmen of all time, whom I could recall, in alphabetical order. Whatever might be the task I undertook I resumed it night after night, beginning as nearly as possible where I left off, and continue until I had completed it.

About a year ago the fancy took me to see how far I could go in raising, by mental process only, the number 3 to its high powers. At the berinning I would not have believed it possible to remember fifteen figures in their order. To my surprise I succeeded in raising 3 to the $44^{\text {th }}$ power, making, if I remember rightly, a number of 22 figures. I did it by successive multiplications by 3 , and without shortening the process in any way. I did not put a figure on paper until I had reached the 24 th power; but always proved every result as far as I could by the nine test-a safeguard against substantially every error save those that might arise from transposition of figures. At the point mentioned I set the product down, and performed on paper this short process :

$$
3^{2}=9 ; 3^{4}=8 \mathrm{I} ; 3^{8}=656 \mathrm{I} ; 3^{21}=656 \mathrm{I} \times 656 \mathrm{I} \times 656 \mathrm{I} \text {. }
$$

As my mental result was wrong in four or five figures in the middle, so to speak, I knew that I must have transposed two figures somewhere between power I 5 and power 20 , so I went back and began over again. At the 24 th power I was right, and so I was when I reached the $44^{\text {th }}$ power.

That seemed to be as far as it was worth while to go, and I then began a more difficult exercise : to ascertain, as in permut ations, the product of the numbers from one upward as far as I could go. I have carried the process up to, and including the number 37 . The product is a number of 44 figures, whereof the last eight are o's, which do not add to the effort of memory to retain them. To remember 36 digits in their correct order may not be a wonclerful feat; it is so easy to me that I do not suppose it is unusual. But I can now remember, and have to-day written down and then repeated to my stenographer, successively, the product of the numbers to 35 , to 36 , and to 37 , having respectively 33,34 and 36 figures, beside the eight o's with which each number ends, or IO 3 figures in all. How much further I could carry the process I do not know; I lo not purpose attempting to ascertain.

I will add some facts that may be interesting.

(I) I verify my result after each multiplication: first, by proving that the sum of all the digits is a multiple of 9 ; secondly, by dividing it by 7 , I I and 13 , not attempting to NO. I 5 I6, VOL. 59$]$ remember the quotient, but only the successive remainders, to be sure that the number divides evenly.

(2) Almost every product has some peculiar combination of numbers. For example, in the 35 result there are four 6's together; in the 36 the figures 6789 occur; the first six figures of the 37 product are 137,637 ; and so on.

(3) The work is done in groups of three figures, and almost every new factor in the multiplication gives some short process of multiplying. Before I begun with 37 it seemed impossible to multiply 34 figures by such a number, odd, large, and a prime number. But the fact that $37 \times 3=$ r I I soon suggested the way to make the process easy. The last nine figures (omitting o's) of the 36 product are $48 \mathrm{I}, 508,352$. Now $352=360(3 \times 12 \times 10)$ -8 . Then we have I I I $\times 12=1332 \times 10=13,320.37 \times 8=296$. I $3,320-296=13,024$. The multiplication of the next group is easy. $37 \times 500=18500$; add $296(37 \times 8)+13$ ("carried") $=18$, 809 . The next group, $48 \mathrm{I}$, is taken as $=500-20+1$, and the number with the is "carried" from the last multiplication becomes i 7,8 I $5,809,024$.

(4) Does this exercise put me to sleep? O, yes, very quickly! Boston, U.S.A., October 24. E. S.

\section{The Leonids in 1868 .}

I WiTnEsSeD the magnificent shower of Leonid meteors on the night of November I3-I4, I 866. But I do not recollect seeing any published account of such a display in England in I868. It occurs to me that the following observations may be worth publishing.

On November 5 in that year I was in Venice. Returning through Milan, I crossed the Alps in a sledge by the St. Gothard in a terrible snow-storm on the 7 th, and reached Calajs at mid-

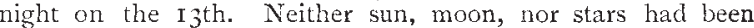
visible since I left Venice. The Calais boat started for Dover about $\mathrm{rh}$. 3om. on the morning of the $\mathrm{I} 4 \mathrm{th}$. As we were leaving the port the clouds suddenly cleared off, and a splendid display of Leonids was visible. I judged the shower to be in every respect equal to that of I 866 . Some of then: were as bright as Jupiter, and left long trails in the sky which took two or three minutes to dissolve. The display kept up until we were within a couple of miles of Dover, when the clouds suddenly came on again and the sky was completely obscured.

Coventry, November 12 .

WM. ANDREWS.

\section{The Smell of Earth}

"SEE, the smeil of my son is as the smell of a field which the Lord hath blessed." Thus poetically spoke the Patriarch lsaac. The man of modern science tells us, prosaically, that the odour of moist earth is due to a bacterium, named Cladothrix odorifera. I write to ask if any one has yet accounted for the well-known and peculiar odour, yielded by clay and clayey rocks when breathed upon. This odour can scarcely be due to bacteria, for it is manifested by cabinet specimens more than twenty years old. Pure alumina appears to be odourless. Leeds, November 12.

C. T. WhitMeli

\section{Breath-Figure of Spider's Web}

A FEll mornings ago I noticed in my bath-room a spider's web spun right across one pane of the window, but not in actual contact with the glass, there being room for at house-fly to buzz up and down the pane without touching the meshes. My morning ablutions giving rise to some considerable quantity of vapour, I observed a very distinct breath-figure of the spider's web apon the glass. I accordingly removed the web and the spider. Next morning, in the absence of the web, on the renewal of the vapoutr conditions the breath-ficure reappeared. I then wiped one half of the window dry with a towel. Now, after five mornings, the breath-figure is quite distinct upon the half which was not touched, and can be faintly seen on the wiped portion.

\section{Charterhouse, Godalming, November 13}

\section{A Second Crop of Apples.}

I THLik perhaps it may be worth noting that apple-blossom was gathered in the neighbourhood of Exeter last week. Still more remarkable is the fact that a second crop of apples has made fair progress, as some at the farm of Cris Lawn, close to the city, some "Red Quaranders" have been gathered, nearly the size of walnuts. Two of these, now somewhat shrivelled. are enclosed.

Exeter, October I4.
JAMES DALlas. 